\title{
STUDI PENDAHULUAN: KONSTRUKSI KEBIJAKAN PENGELOLAAN SAMPAH DI KOTA PEKANBARU 2012-2014
}

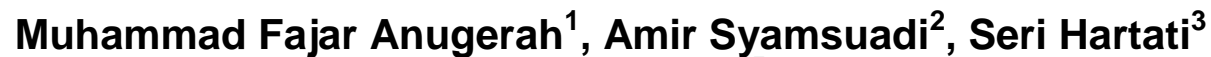 \\ Diki Arisandi ${ }^{4}$, Liza Trisnawati ${ }^{5}$, Roni Saputra ${ }^{6}$ \\ 1,2,3 IImu Pemerintahan Universitas Abdurrab \\ ${ }^{4,5}$ Teknik Informatika Universitas Abdurrab \\ ${ }^{6}$ Ilmu Keperawatan Universitas Abdurrab \\ fajar.anugerah@univrab.ac.id, amir.syamsuadi@univrab.ac.id, seri.hartati@univrab.ac.id \\ diki@univrab, liza.trisnawati@univrab.ac.id, roni.saputra@univrab.ac.id
}

\begin{abstract}
Pekanbaru City has problems related to waste control which is a homework for the Government and society. Based on statistical data on population spikes in Pekanbaru City of $1,100,000$ people / year and the volume of waste generated is $2,750 \mathrm{m3}$, assuming everyone produces 2.5 liters of waste / day. The amount of waste transported to landfills (TPA) currently reaches 1,667 m3 / day, so the coverage of the Pekanbaru city waste transportation service coverage is $40.91 \%$. This study aims to identify the design of government policies to solve the waste problem in Pekanbaru City. This study uses a qualitative research approach and triangulation techniques so that it gets an overview of the policy design made by the Pekanbaru City Government in overcoming this waste problem. The results showed that the form of policy plans carried out by the Pekanbaru City government was formulated through a waste clean area action plan policy scheme by optimizing the institutional functions that are responsible for waste management, strengthening regulatory functions, and improving technical operational waste management.
\end{abstract}

Keywords: design, policy control, trash, urban

\begin{abstract}
Abstrak
Kota Pekanbaru memiliki problematika terkait pengendalian sampah yang merupakan pekerjaan rumah bagi Pemerintah dan masyarakat. Berdasarkan data statistik lonjakan penduduk di Kota Pekanbaru sejumlah 1.100.000 jiwa/tahun dan volume sampah yang dihasilkan mencapai sebesar $2.750 \mathrm{~m}^{3}$ dengan asumsi setiap orang menghasilkan sampah 2,5 liter/hari. Jumlah sampah yang yang diangkut ke tempat pembuangan akhir (TPA) saat ini mencapai $1.667 \mathrm{~m}^{3} /$ hari maka capaian cakupan pelayanan pengangkutan sampah kota Pekanbaru adalah 40,91\%. Penelitian ini bertujuan untuk mengidentifikasi rancangan kebijakan pemerintah untuk menyelesaikan permasalahan sampah di Kota Pekanbaru. Penelitian ini menggunakan pendekatan penelitian kualitatif dan teknik triangulasi sehingga mendapat gambaran mengenai rancangan kebijakan yang dibuat oleh Pemerintah Kota Pekanbaru dalam menanggulangi permasalahan sampah ini. Hasil penelitian menunjukkan bahwa bentuk rencana kebijakan yang dilakukan oleh pemerintah Kota Pekanbaru disusun melalui skema kebijakan rencana aksi daerah bersih sampah dengan mengoptimalisasikan fungsi kelembagaan yang bertanggung jawab dalam pengelolaan sampah, menguatkan fungsi regulasi, dan membenahi teknis operasional pengelolaan sampah.
\end{abstract}

Kata kunci: rancangan, kebijakan, pengendalian, sampah, perkotaan 


\section{PENDAHULUAN}

Di Indonesia permasalahan sosial ditemukan baik di tingkat pedesaan maupun di perkotaan, tetapi lebih banyak peluang masalah-masalah sosial tersebut muncul di perkotaan.Oleh karena itu, urban management (pengelolaan perkotaan) dilaksanakan sebagai suatu proses manajemen dari keadaan kondisi sistem kota saat ini menuju sistem kota yang dikehendaki berdasarkan pada kondisi ideal yang diharapkan. Fokus manajemen perkotaan sangat berhubungan dengan kebutuhan aspek fisik, sosial maupun ekonomi masyarakat (Alam 2016). Sampah kota diartikan sebagai sampah yang dibuang oleh masyarakat kota. Permasalahan sampah kota adalah volume sampah besar dan melebihi daya tampung tempat pembuangan akhir (TPA) (Mulasari, Husodo, \& Muhadjir 2016).

Jumlah Penduduk Kota Pekanbaru diproyeksikan pada tahun 2020 meningkat sebesar $42 \%$ dibandingkan jumlah penduduk pada tahun 2011, yaitu dari 937.939 jiwa bertambah menjadi 1.334.980 jiwa dengan asumsi tingkat pertumbuhan penduduk mencapai rata-rata 4\% per tahun. Adapun Luas RTH yang menjadi Kewajiban Dinas Kebersihan dan Pertamanan Kota Pekanbaru sesuai dengan amanat Rencana Tata Ruang Tata Kota Pekanbaru s/d tahun 2033 adalah $5.018 \mathrm{Ha}$, terdiri dari : Luas hutan kota $1.447 \mathrm{Ha}$, taman kota $1.447 \mathrm{Ha}$ dan Taman Median Jalan $413 \mathrm{Ha}$. Eksisting Total Luas RTH yang dipenuhi DKP adalah 27,83 artinya capaian luas RTH baru mencapai $0,55 \%$ dari target. Kekurangan Luas RTH yang harus dipenuhi oleh DKP sampai dengan tahun 2033 adalah 4.990,17 Ha (Dinas Lingkungan Hidup Kota Pekanbaru, 2017). Pertambahan penduduk ini akan berdampak pada peningkatan volume sampah, terutama di perkotaan. Permasalahan pokok lainnya mengenai perilaku masyarakat urban yakni terkait kepedulian terhadap lingkungan. Tidak dapat dipungkiri bahwa masyarakat perkotaan cenderung lebih individualistik, hal ini dikarenakan mereka lebih mementingkan kepentingan pribadi diatas kepentingan masyarakat secara umum (Syamsuadi and Zainuddin 2018). Secara praktis penelitian ini bertujuan untuk untuk mengidentifikasi rancangan kebijakan pemerintah untuk menyelesaikan permasalahan sampah di Kota Pekanbaru.

\section{KAJIAN PUSTAKA}

Kebijakan pengelolaan sampah berdasarkan Peraturan Daerah Kota Pekanbaru Nomor 4 Tahun 2000 tentang Retribusi Pelayanan Persampahan dan Kebersihan sebagaimana telah diubah dengan Peraturan Daerah Kota Pekanbaru Nomor 10 Tahun 2012 tentang retribusi pelayanan persampahan/ kebersihan sudah tidak cukup lagi menjadi rujukan pengaturan persampahan Perda tersebut lebih berorientasi pada penanganan kebersihan lingkungan saja dan penekanan kewajiban masyarakat membayar retribusi. Konsep penanganan sampah hanya ditekankan pada pengumpulan sampah, pengangkutan dan penimbunan di tempat pembuangan akhir (TPA).

Hal ini juga sudah tidak sesuai dengan Undang-undang Nomor 18 tahun 2008 tentang Pengelolaan Sampah dan Peraturan Pemerintah Nomor 81 tahun 2012 tentang pengelolaan sampah rumah tangga dan sampah sejenis sampah rumah tangga. Kedua perundang-undangan tersebut membawakan perubahan-perubahan sangat mendasar dalam pengelolaan sampah, baik menyangkut keseluruhan cara berpikir (mindset), orientasi dan spirit serta konsepsi kebijakan pengelolaan sampah.Berdasarkan perubahan-perubahan tersebut, pengelolaan sampah kemudian menghasilkan banyak agenda perubahan kebijakan dalam pengelolaan sampah, yang 
tentunya harus diacu oleh setiap daerah dalam kebijakan pengelolaan sampah didaerahnya masing-masing yang merupakan esensi penata kelolaan pemerintahan yang baik. Tata pemerintahan adalah penggunaan wewenang ekonomi, politik dan administrasi guna mengelola urusan-urusan negara pada semua tingkat (Syamsuadi 2018).

Beberapa kajian mengungkapkan kebijakan persoalan penyelesaian sampah diwilayah perkotaan. Pertama, kajian yang mengungkapkan permasalahan sampah Kota Yogyakarta dan penangulangannya (Mulasari, Husodo, dan Muhadjir 2014). Dimana hasil dari kajian penelitian tersebut menemukanbahwa penyumbang sampah terbanyak Kota Yogyakarta adalah di TPA Piyungan, kemudian Kabupaten Sleman dan Bantul. Volume sampah tertinggi pada 2012 dan terus menurun sampai tahun 2014. Semua permasalahan ada dari sisi hilir (masyarakat), proses (pengelola sampah) dan hulu (TPA). Setelah semua diidentifikasi, dibuat suatu kebijakan pengelolaan sampah secara optimal dengan melibatkan semua lintas sektoral dan program-program pemberdayaan oleh stakeholder terkait (Mulasari, Husodo, \& Muhadjir 2014). Kebijakan untuk pengelolaan sampah di seluruh kabupaten/kota Daerah Istimewa Yogyakarta (DIY) telah terbentuk badan/unit yang bertanggung jawab mengelola sampah. Metode pemantauan dan evaluasi kebijakan pengelolaan sampah di DIY belum dituangkan dalam prosedur baku. Kebijakan telah didukung dengan program layanan, proyek, regulasi, dan insentif khusus untuk pengelolaan sampah (Mulasari, Husodo, \& Muhadjir 2016).

Kedua, penelitian mengenai model kebijakan pengelolaan sampah berbasis partisipasi "green community" mendukung Kota Hijau (Suyanto et al. 2015). Penelitian dilakukan di Kota Purwokerto, metode yang digunakan pendekatan kualitatif (triangulasi) dan kuantitatif (survei, AHP). Hasil menunjukkan bahwa partisipasi green community berbasis pola kerigan dalam pengelolaan sampah green waste meliputi kelembagaan, pemberdayaan, aktivitas pelaksanaan, kerjasama, pendanaan, belum maksimal. Model kebijakan pengelolaan sampah green waste berbasis green community mendukung kota hijau, hasil AHP menunjukkan bahwa partisipasi green community merupakan prioritas pertama yang harus diperhatikan. Strategi kebijakan yang perlu dilakukan yaitu melibatkan green community, revitalisasi kearifan lokal pola kerigan, memperbanyak bank sampah, taman kota, bank pohon, revitalisasi manajemen, sosialisasi gerakan "pungut sampah", revitalisasi manajemen, deposit sampah, asuransi sampah dengan mengedepankan ekoliterasi dan ekodesain serta revolusi mental (Suyanto et al. 2015).

Ketiga, kajian penelitian evaluasi kebijakan pengelolaan sampah di TPA Gunung Panggung Kabupaten Tuban. Esensi penelitian ini adalah mengevaluasi kebijakan pengelolaan sampah di Gunung Panggung TPA Kabupaten Tuban dengan pendekatan lima kriteria, yaitu keefektifan, ketepatan, kecukupan, kesetaraan, dan responsitas serta memberi saran/rekomendasi tindakan korektif yang harus diambil oleh Pemerintah Tuban dalam mengelola pengelolaan sampah di TPA Gunung Panggung. Hasil penelitian Menunjukkan bahwa pengelolaan sampah masih terkendala fleksibelitas anggaran, stakeholder pelaksana, kapasitas TPA Gunung Panggung yang minim, kesadaran masyarakat dalam mengelola sampah,pembayaran retribusi dan kebijakan yang belum responsif terhadap masyarakat (Mayangkara 2016).

Keempat, kajian yang relevan berikutnya adalah program inovasi pengelolaan sampah di Kota Malang. Penelitian ini menggunakan medote penelitian deskriptif kualitatif. Hasil penelitian menunjukkan bahwa inovasi pengelolaan sampah lebih 
banyak muncul dari kalangan masyarakat. Strategi inovasi pengelolaan sampah yang dilakukan DKP dengan merangkul penggiat lingkungan yang dilakukan dengan mengembangkan dan mengajak sosialisasi penggiat lingkungan. Efektivitas kebijakan pengelolaan sampah sudah efektif namun belum optimal, yang disebabkan oleh beberapa faktor. Dampak pengelolaan sampah yaitu kesadaran masyarakat mulai terbentuk, tambahan pendapatan bagi masyarakat dan diraihnya Adipura Kencana (Lestari 2014).

Kelima, kajian mengenai Implementasi Kebijakan Pengelolaan Sampah Kota Semarang Menurut Perda Nomor 6 Tahun 2012 Tentang Pengelolaan Sampah. Tujuan penelitian ini adalah untuk mengetahui bagaimana implementasi dan faktor yang mendorong dan menghambat implementasi Kebijakan Pengelolaan Sampah Kota Semarang menurut Perda Nomor 6 Tahun 2012. Hasil Penelitian ini menunjukan bahwa Implementasi Kebijakan Pengelolaan Sampah belum sepenuhnya berhasil untuk mengurangi jumlah timbulan sampah yang ada. Dalam pelaksanaannya masih terdapat berbagai kendala seperti, komunikasi, sumber daya, disposisi dan struktur birokrasi. Rekomendasi yang dapat diberikan untuk masalah tersebut seperti sosialisasi perda melalui media elektronik, penambahan sumber daya manusia dan fasilitas kebersihan, pelatihan motivasi untuk pegawai serta pembentukan bagian khusus yang menangani masyarakat yang melanggar peraturan yang sudah ditetapkan (Yulistia, Suryaningsih, \& Rostyaningsih 2015).

Dengan segala kekhasannya, kajian konstruksi kebijakan sampah diperkotaan masih minim ditemui. Kajian khusus yang membahas mengenai konstruksi kebijakan sampah di Kota Pekanbaru juga belum ditemui. Oleh karena itu, hasil dari ulasan literatur yang sudah dilakukan kemudian diformulasikan dalam penelitian dengan menempatkan institusi dan regulasi pengelolaan sampah di Kota Pekanbaru sebagai subjek penelitian dan Pengelolaan sampahsebagai fokus penelitian dari sudut pandang kebijakan publik (public policy). Kajian terdahulu yang telah dikemukakan sebelumnya digunakan sebagai acuan untuk menjalskan kajian konstruksi kebijakan pengelolaan sampah di Kota Pekanbaru.

\section{Gambar 1. Kerangka Teoritis}

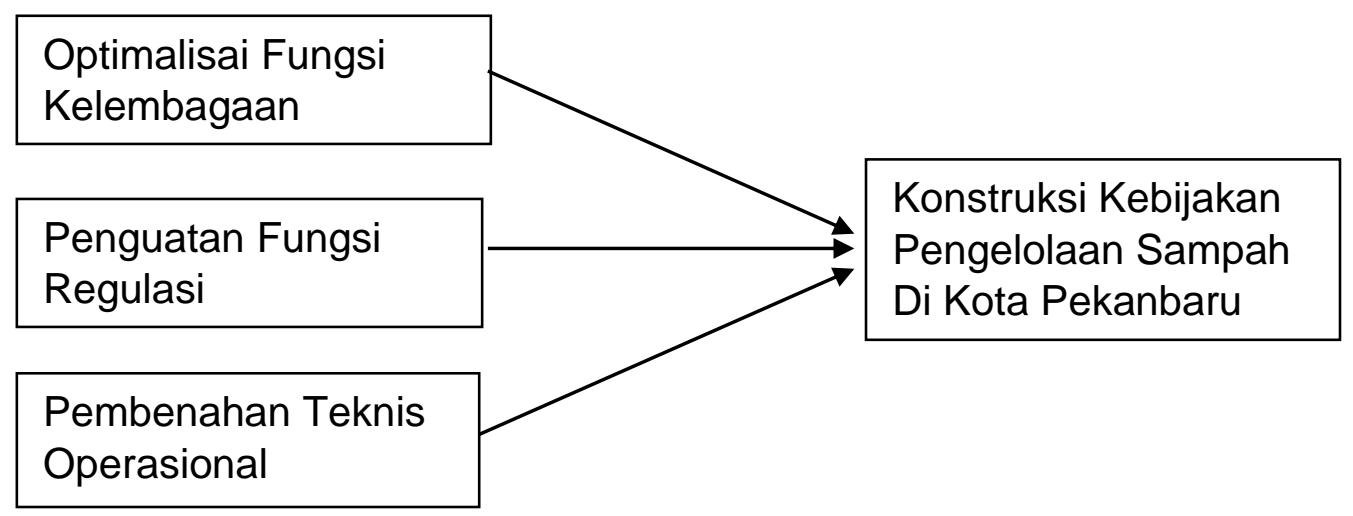

Sumber: Analisis penulis, 2020

\section{METODE PENELITIAN}

Jenis penelitian ini adalah kualitatif dengan rancangan studi kasus. Penelitian ini memberi pengetahuan terjadinya fenomena pada individual, organisasi, sosial dan 
politik. Konsep triangulasi dipergunakan untuk menanggapi secara positif kelemahan yang ada, menggunakan metode dan sumber data secara berganda(Mulasari, Husodo, \& Muhadjir 2016).

Pendekatan kualitatif dapat dipahami dari tiga aspek. la dapat dimaknai sebagai: (1) sebuah pendekatan induktif antara teori dan penelitian, dimana teori dihasilkan dari hasil penelitian atau analisis data, (2) sebuah posisi epistimologis yang dideskripsikan layaknya interpretivis yang menekankan pada pemahaman dunia sosial melalui sebuah pengujian interpretasi atau pemaknaan dunia sosial oleh partisipannya dan (3) sebuah posisi ontologis yang dideskripsikan layaknya kontruksionis yang menyiratkan bahwa properti-properti dunia sosial adalah hasil dari interaksi antar individu (Bryman 2016)

Analisis data adalah proses mencari dan menyusun secara sistematis data yang diperoleh dari hasi wawancara, catatan lapangan, dan dokumentasi, dengan cara mengorganisasikan data ke dalam kategori, menjabarkan ke dalam unit-unit, melakukan sintesa, menyusun ke dalam pola, memilih mana yang penting dan yang akan dipelajari, dan membuat kesimpulan sehingga mudah dipahami oleh diri sendiri maupun orang lain. Berdasarkan tujuan penelitian, penelitian ini menggunakan metode analisis data dengan pendekatan kuantitatif. Analisis dilakukan terhadap data hasil studi pendahuluan atau sekunder, yang akan digunakan untuk menentukan fokus penelitian(Sugiyono 2015). Pemaknaan terhadap fenomena terkait dilakukan dengan mengumpulkan data yang relevan untuk menemukan jawaban atas pertanyaanpertanyaan yang diajukan dalam penelitian (Setiawan, Saputra, \& Wahyudi 2020).

Penelitian ini dilaksanakan di Kota Pekanbaru, informan penelitian terdiri dari Emma Urina Silalahi selaku staff Badan Lingkungan Hidup Kota Pekanbaru, Zulfikri yang merupakan Kepala Badan Lingkungan Hidup Kota Pekanbaru, Edwin Supradana selaku Kepala Dinas Kebersihan dan Pertamanan Kota Pekanbaru, Zulkifli sebagai Kepala Dinas Pekerjaan Umum Kota Pekanbaru, M. Jamal dari Dinas Pendidikan Kota Pekanbaru, dan perwakilan staf di Kecamatan Kota Pekanbaru.

\section{Teknis Pelaksanaan Kebijakan Pengelolaan Sampah di Kota Pekanbaru}

Dikeluarkannya UU No. 18 Tahun 2008 tentang Pengelolaan Sampah menjadi titik awal bagi daerah untuk menata ulang kembali penanganan dan proses pengelolaan sampah. Dari Total produksi sampah beberapa sumber timbulan sampah di Kota Pekanbaru yang mencapai sebesar 3.661,65 $\mathrm{m}^{3}$ atau 1.098 Ton per hari dan apabila dibandingkan dengan jumlah sampah yang terangkut di TPA Muara Fajar saat ini mencapai $1.667 \mathrm{~m}^{3}$ atau 450 Ton per hari $\mathrm{m}^{3}$ maka capaian cakupan pelayanan pengangkutan sampah kota Pekanbaru adalah 40,90\% (Lubis \& Erman 2017).

Tabel I. Cakupan Pelayanan Pengangkutan Sampah Kota Pekanbaru Tahun 2012-2014

\begin{tabular}{cccccc}
\hline No & Tahun & $\begin{array}{c}\text { Timbulan } \\
\text { Sampah }\end{array}$ & $\begin{array}{c}\text { Sampah } \\
\text { terangkut } \\
\text { ke TPA }\end{array}$ & Loss Angkut (Ton) & Rasio (\%) \\
\hline 1 & 2012 & 877 & 305 & 572 & 34.78 \\
\hline 2 & 2013 & 912 & 400 & 572 & 43.86 \\
\hline 3 & 2014 & 1.098 & 500 & 598 & 45.54 \\
\hline
\end{tabular}

Sumber : Dinas Kebersihan dan Pertamanan Kota Pekanbaru, 2017 
Sistem pengelolaan sampah saat ini belum mampu menyelesaikan permasalahan yang ada. Kaji ulang atas perundang-undangan yang berkaitan dengan persampahan dan lingkungan bertujuan untuk mengetahui hal-hal yang terkait, baik secara langsung maupun tidak langsung terhadap pengelolaan persampahan yang telah diatur dalam perundang-undangan yang telah ada.

Mengintegrasikan substansi pengaturan pengelolaan persampahan dalam rancangan peraturan daerah ini dengan undang-undang diatasnya sehinggatidak terjadi pertentangan diantara undang-undang tersebut. Menurut Edwin selaku Kepala Dinas Kebersihan Kota Pekanbaru, Pemerintah harus menpaduserasikan prinsip dan pola pengelolaan sampah sesuai dengan ketentuan yang telah dikeluarkan pemerintah pusat. Sehingga terciptanya link and match antara pusat dan daerah dalam pengentasan persoalan sampah yang terjadi didaerah. Salah satu adalah dari aspek regulasi, ini menjadi pijakan hukum dan panduan umum bagi seluruh daerah termasuk bagi pemerintah kota Pekanbaru untuk mengatur secara teknis sesuai dengan karateristik yang dimiliki daerah masing-masing. Pengolahan sampah melalui daur ulang sampah menjadi pupuk organik (komposting) saat ini menghasilkan 450 Ton per bulan dengan perincian sebagai sebagai berikut:

a) Dinas Kebersihan dan Pertamanan Kota Pekanbaru dengan 6 unit mesin pengolahan komposting menghasilkan 12 ton per bulan.

b) Kantor Pemerintah/Swasta, Rumah Sakit dan Pasar di Kota Pekanbaru menghasilkan 75 ton per bulan.

c) SD, SMP, SMU, SMK dan Perguruan Tinggi di Kota Pekanbaru menghasilkan 158 ton Per bulan.

d) Perumahan, Pemukiman penduduk dan RTH menghasilkan 205 ton per bulan (Lubis and Erman 2017).

Selanjutnya pendapat Edwin, produksi kompos yang dihasilkan tersebut digunakan untuk keperluan penanaman pohon pada kamis menanam setiap minggunya dan untuk taman-taman perkantoran serta taman-taman sekolah yang ada di Kota Pekanbaru. Keterlibatan dalam aksi bersih sampah keberhasilan aksi bersih sampah tergantung pada seberapa jauh interegrasi yang terbangun antara konteks budaya dan sosial setempat, kondisi alam, struktur dan lembaga, kondisi ekonomi dan teknologi yang tersedia dan keterampilan.

Dengan kata lain, hanya program dan proyek yang, terus berinteraksi secara seimbang dengan konteks lokal,menyediakan layanan yang dihargai oleh populasi sasaran, memudahkan untuk populasi sasaran dalam instrumen dan sumber daya yang berguna, teratur menyesuaikan instrumen sesuai dengan pengalaman dan umpan balik yang dapat memberikan kontribusi terhadap aksi bersih sampah.

Dikeluarkannya UU No. 18 Tahun 2008 tentang Pengelolaan Sampah menjadi titik awal bagi daerah untuk menata ulang kembali penanganan dan proses pengelolaan sampah. Aspek-aspek penataan ulang ini sangat banyak terkait dengan sektor kelembagaan serta bidang aturan dan pengetahuan diantaranya:

a) Motivasi dan keterlibatan kelompok setempat

Tingkat motivasi dirasakan olehmasyarakat tergantung pada sejauh mana suatu program dapat menciptakan situasi yang saling menguntungkan antara semua pihak yang berkaitan dengan mempertimbangkan kebutuhan individu dan kolektif (dampak sosial, pengurangan masalah, manfaat, kenyamanan). Untuk alasan ini, semua pihak harus dilibatkan dalam pengambilan keputusan yang mempengaruhi mereka. Perhatian khusus harus diberikan pada peraaturan tradisional dan hak- 
hak mengenai pengelolaan sampah. Dalam aksi ini, perempuan khususnya memiliki cukup tanggung jawab. Jika perempuan tidak termasuk dalam keputusan, kebutuhan dan berkontribusi pada aksi, maka pihak tersebut akan salah menilai. Hal ini sering dapat menyebabkan kesalah pahaman dan perencanaan akan tidak memadai. Aksi bersih sampah berdampak pada hubungan sosial (distribusi daya dan tenaga kerja antara laki-laki dan perempuan, tradisional dan otoritas modern, populasi nomaden dan berpindah-pindah, dan lain-lain). Perencana harus sadar bahwa baik masalah tersembunyi atau terbuka mungkin timbul. Namun, penciptaan manajemen yang seimbang dan metode partisipatif pengambilan keputusan merupakan solusi yang biasa dapat diterima.

b) Pengelolaan Berbasis Masyarakat

Strategi Manajemen Berbasis Masyarakat menunjukkan perilaku transparan pada bagian dari semua pihak dalam aksi ini. Ini termasuk pilihan metode negosiasi yang tepat untuk menilai kebutuhan riil dan potensi struktur setempat. Solusi alternatif harus dikembangkan dan dibandingkan. Salah satu tugas utama dalam pengelolaan berbasis masyarakat adalah untuk menegosiasikan distribusi wewenang dan tanggung jawab di antara berbagai pihak yang bersangkutan. Tanggung jawab harus diambil sejauh mungkin oleh pengguna, dan harus berdasarkan aturan tradisional pengelolaan sampah. Kebijakan nasional sektor, serta rencana pembangunan daerah dan perkotaan, harus mencakup dan mendukung promosi sistem pengelolaan sampah yang dikelola sendiri di tingkat kelembagaan yang tepat (Fuad 2014).

c) Partisipasi

Kerjasama antar pihak Partisipasi kerjasama yang transparan dan komprehensif dalam fakta dan harapan. Hal ini membuat keputusan yang lebih baik dan mudah diterima. Juga dapat menciptakan kesempatan bagi pembelajaran yang interaktif dan untukmengedepankan komitmen, motivasi, kemitraan dan rasa tanggung jawab dan rasa memiliki.

d) Pengalihan kepemilikan

Tujuan utama dari pendekatan partisipatif menurut Zulfkri selaku Kepala Badan Lingkungan Hidup Kota Pekanbaru adalah untuk menumbuhkan rasa memiliki dari semua pihak. Kepemilikan dimulai dengan perencanaan dan proyek memastikan keterlibatan pengguna pada setiap tahap proses, dari analisis masalah pada melalui perencanaan, pelaksanaan dan konsolidasi.Sementara kepemilikan melalui partisipasi merupakan tujuan langsung, realisasi itu sendiri, di hubungannya dengan tujuan aksi kesetaraan dan keberlanjutan, tantangan yang ditemui. Masyarakat tidak homogen tetapi sangat bertingkat dalam hal kekayaan, kekuasaan dan pola kepemilikan. Perhatian utama dari aksi ini yaitu harus fokus dalam kegiatan pengenalan pada lingkungan sosial yang kecil dan homogen. Berdasarkan pengalaman koperasi yang positif dalam kelompok ini, memudahkan untuk mendekati masalah yang lebih kompleks yang mempengaruhi masyarakat di lingkup yang lebih besar.

e) Struktur Gender

Seperti yang diketahui bahwa wanita merupakan pengatur di tingkat domestik dan kesehatan keluarga. Tetapi pada tingkat aksi terkendala pada fisik mereka dalam 
konstruksi dan perawatan. Kemampuan wanita dan kapasitas dalam membuat keputusan, manajemen dan produksi ekonomi menerima terlalu sedikit perhatian dan harus dipromosikan.Wanita dan pria memiliki pembeda tekhnik spesifik, sosial dan ekologi pengetahuan dan pengalaman, serta bentuk-bentuk mereka sendiri dalam organisasi, yang dapat memberikan kontribusi untuk meningkatkan infrastruktur. Dalam perencanaan, pelaksanaan dan evaluasi aksi bersih sampah, perempuan dan laki-laki harus dilibatkan sebagai pihak dengan hak yang sama, dan hambatan yang ada untuk partisipasi mereka harus dihilangkan atau dikurangi. Secara teknikal, cara kelembagaan dan pendidikan atau pelatihan yang diterapkan harus disesuaikan dengan kebutuhan dan kemampuan mereka. Pembangunan gender yang seimbang berarti bahwa kegiatan aksi harustidak memiliki efek negatif pada perempuan dan pada hubungan gender yang berlaku,setidaknya menguntungkan bagi perempuan untuk laki-laki,memberikan prioritas kepada perempuan karena mereka paling bertanggung jawab untuk anak-anak.

f) Integrasi Sosial dalam Aksi

Aksi dan teknologi harus dapat diterima. Jeli dalam memfilter hoax, dimana hoax merupakan berita palsu yang mengandung informasi yang sengaja menyesatkan orang dan memiliki agenda tertentu (Syamsuadi et al. 2019). Dengan begitu jalinan itegrasi sosial yang diinginkan oleh keluarga dalam lingkungan sosial yang berbeda dan kelompok dapat tercapai. Menjaga hubungan baik antara pemerintah daerah, anggota badan publik dan masyarakat umum yang terpilih dan dinominasikan, menfasilitasi komunikasi dan kerjasama.

g) Manajemen perubahan dan dinamisme kerjasama

Perubahan menciptakan ketidakpastian dan ketakutan. Aksi merupakan proses mencairkan perubahan dan konsolidasi, perlu diskusi yang luas antara orang-orang yang bersangkutan dan pendampingan yang berkompeten. Fase konsolidasi merupakan proses membanggun kepercayaan dan kapasitas, yang membutuhkan waktu serta upaya lokal dan dukungan eksternal. Periode keterlibatan dan masukan yang diperlukan, terutama untuk fase konsolidasi, sering diremehkan.

h) Kelembagaan:

1. Keterlibatan LSM dan Sektor Swasta

Aksi didasarkan pada hak-hak dan tanggung jawab bersama antara pemegang sektor publik dan swasta. sedangkan tanggung jawab untuk hukum dan ketertiban harus bergantung pada sektor publik, keterlibatan sektor swasta dan LSM sebagai mitra dalam tugas dan kegiatan lainnya dapat memperoleh keuntungan yang sinergi dan efisiensi yang lebih besar pada pihak masingmasing (kurang birokrasi).Berbasis lokal dan LSM yang dikelola dapat menjadi mediator yang baik antara pemangku aksi dan sektor publik. Mereka sering mengembangkan mekanisme untuk pelaksanaan aksi yang memenuhi kebutuhan populasi yang bersangkutan.Interaksi yang ditingkatkan antara pemangku aksi dan sektor swasta dapat juga berkontribusi terhadap peningkatan kualitas aksi. Peningkatan keterlibatan swasta dapat meningkatkan efisiensi dan mengurangi biaya. 
2. Penguatan lembaga/ Institusi

Penguatan kapasitas kelembagaan dari berbagai pelaku dapat dicapai dengan cara yang berbeda, misalnya kegiatan pelatihan yang sudah ditargetkan, dukungan dalam penciptaan atau adaptasi struktur kelembagaan tertentu, atau penyederhanaan prosedur administrasi internal, khususnya yang berhubungan dengan desentralisasi kegiatan. Untuk memperkuat kapasitas kelembagaan, kondisi kontekstual yang jelas perlu ditetapkan oleh kebijakan sektor nasional (berdasarkan proses partisipatif yang melibatkan semua kelompok yang relevan dari masyarakat).Koordinasi dan kolaborasi antara lembaga pemerintah, LSM dan sektor swasta membutuhkan definisi yang jelas tentang peran masing-masing pihak, terutama dalam hal yang diharapkan oleh setiap masing-masing pihak. Dalam hal ini, komunikasi yang jelas dan adil komunikasi yang sangat penting. Keberhasilan pelaksanaan aksi bersih sampah tergantung pada struktur administrasi nasional dengan instrumen eksekutif yang memadai.

\section{Perubahan institusional dan fleksibilitas}

Organisasi dan struktur terus-menerus melalui proses-proses perubahan. Dinamika ini membawa risiko dan peluang pada saat yang sama. Kebutuhan adaptasi struktural dan fleksibilitas keseluruhan harus selalu diingat.

\section{i) Kondisi Ekonomi dan Teknologi}

Harga dan model pembiayaan yang tepat untuk investasi dan biaya rutin memainkan peran kunci berkaitan dengan keberlanjutan sistem ekonomi. Seringkali, kebijakan pembayaran menambah beban konsumen miskin. Dan juga kodisi ekonomi suatu daerah sangat menentukan pembiayaan dalam program aksi bersih sampah. Sistem pengelolaan sampah harus berteknologi yang sesuai dan tidak menimbulkan dampak negatif pada lingkungan(Damanhuri and Padmi 2010).

Teknis kesesuaian harus didefinisikan dan dinegosiasikan dengan pengguna selama kelayakan studi.Aspek seperti ketersediaan pengetahuan, keterjangkauan, bahan lokal dan fasilitas pelatihan serta konteks sosial di mana infrastruktur yang telah ada harus dipertimbangkan. Dengan cara ini pengenalan risiko baru dalam sistem yang baru dapat dikurangi. Perubahan tersebut terhadap risiko pengelolaan sampah menurunkan ekologi dan terdapat risiko kesehatan, menciptakan ekonomi (biaya pemeliharaan) baru, politik (dependensi) dan risiko sosial (melemahnya struktur yang ada, aturan dan peraturan serta keterampilan dan pengetahuan).

Sebuah konsep jangka panjang biasanya lebih tepat daripada konsep berskala besar dan. Lebih dapat diterima jika mengupgrade sistem operasi dan pemeliharaan yang ada untuk memperbaiki dan merehabilitasi prasarana dan sarana yang tidak dapat beroperasi daripada mengadakan atau membuat prasarana dan sarana yang baru. Sistem pembangunan lokal atau komponen tunggal harus lebih dipromosikan.

Organisasi pemerintah dan organisasi pendidikan lebih peka dan melakukan penyesuaian, sehingga mampu bersaing di tengah perkembangan peradaban Revolusi Industri 4.0 guna tetap survive dalam menjalankan tugas pokok dan fungsinya dengan lebih efesien dan efektif sebagai responsit terhadap meningkatnya tuntutan akuntabilitas dan transparasi publik (Hartati, Syamsuadi, \& Elvitaria 2020). 
j) Peraturan dan Pengetahuan

Waktu dan energi selalu diinvestasikan dalam pengalaman transmisi dan nilai-nilai dari satu generasi ke yang berikutnya. Transmisi pengetahuan selalu terkait dengan budaya latar belakang dan organisasi sosial suatu masyarakat. Kebanyakan pembagian kerja yang berfungsi pada masyarakat berdasarkan dengan jenis kelamin dan kelompok perofesional, serta antara keluarga dan masyarakat. Setiap segmen memiliki pengetahuan sendiri (pengalaman) dan aturan (mendefinisikan hak dan kewajiban). Pengetahuan masyarakat atau pengguna di bidang sosial dan teknis membentuk dasar untuk aksi bersih sampah berkelanjutan.

\section{Gambar 2.Kerangka Model Kebijakan Pemerintah terkait Pengelolaan Sampah}

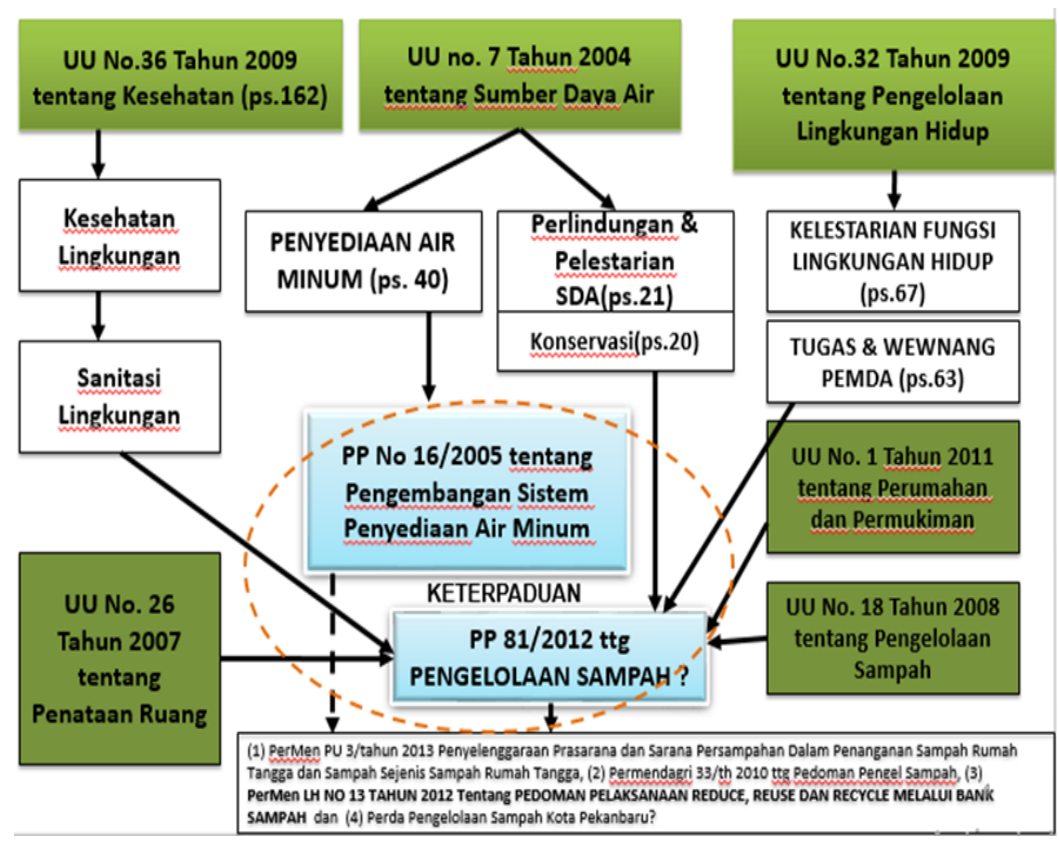

Sumber: Data analisis penelitian, 2020

Hal ini sangat penting bagi keberlangsungan aksi untuk mengidentifikasi pengetahuan dan pengaruh dari setiap kelompok dalam masyarakat lokal, dan untuk mengintegrasikan potensi mereka dalam operasi dan peningkatan pengelolaan sampah. Fungsi dari aksi bergantung pada setelah pelaksanaan aksi itu sendiri. Karena setiap masyarakat mengalami perubahan, mempromosikan kapasitas pemecahan masalah penerima manfaat dapat memupuk sosial budaya keberlanjutan. Spirit dalam UU No.18/ 2008 (UUPS) dan PP No.81/ 2012 mengisyaratkan pengelolaan sampah tidak lagi menghendaki adanya eklusifitas kebijakan pengelolaan sampah oleh satu pihak tertentu saja. Regulasi UU persampahan juga menekankan orientasi pada tujuan, yaitu melidungi masyarakat dan lingkungan hidup dari bahaya pencemaran dan bencana sampah sebagaimana diamanatkan juga dalam UUD 1945 pasal $28 \mathrm{H}$ yakni setiap orang berhak mendapatkan lingkungan hidup yang baik dan sehat.

\section{Wilayah, Fungsi dan Tugas Organisasi Perangkat Daerah (OPD)}

Penguatan fungsi kelembagaan bidang pengelolaan sampah di Kota Pekanbaru untuk menciptakan kelancaran dan ketertiban dalam mengelola persampahan/kebersihan di 
Kota Pekanbaru, telah diterbitkan Keputusan Walikota Pekanbaru Nomor 7 Tahun 2004 tentang Petunjuk Pelaksanaan Pengelolaan Kebersihan di Kota Pekanbaru yang mengatur pembagian kewenangan dan tugas pengelolaan kebersihan. kewenangan dan tugas tersebut yaitu:

1) Dinas Kebersihan dan Pertamanan Kota Pekanbaru, yang bertugas sebagai koordinator pengelolaan kebersihan di Kota Pekanbaru dan mengelola Kebersihan di 24 ruas Jalan-jalan Protokol.

2) Dinas Pasar Kota Pekanbaru, yang bertugas mengelola kebersihan di pasar-pasar di Kota Pekanbaru.

3) Dinas Pekerjaan Umum Kota Pekanbaru, yang bertugas mengelola kebersihan pada saluran air, selokan dan anak sungai.

4) Dinas Perhubungan, Komunikasi dan Informatika Kota Pekanbaru, yang bertugas mengelola kebersihan di terminal dan pelabuhan.

5) Dinas Pendidikan Kota Pekanbaru, yang bertugas mengelola kebersihan di sekolah-sekolah.

6) Badan Lingkungan Hidup Kota Pekanbaru, yang bertugas menangani limbah B3, limbah industri dan pemantauan pencemaran.

7) Kecamatan se-Kota Pekanbaru, yang bertugas mengelola kebersihan di wilayah kecamatan masing-masing.

\section{1) Dinas Kebersihan dan Pertamanan Kota Pekanbaru}

Dinas Kebersihan dan Pertamanan Kota Pekanbaru mempunyai tugas pokok melaksanakan sebahagian pemerintah daerah di bidang kebersihan dan pertamanan. Berdasarkan Pasal 675 Peraturan Daerah Kota Pekanbaru Nomor 8 Tahun 2008 tentang Pembentukan Susunan Organisasi, Kedudukan dan Tugas Pokok Dinas Kebersihan Kota Pekanbaru adalah:

1) Perumusan kebijakan teknis di bidang kebersihan dan pertamanan;

2) Penyelenggaraan urusan pemerintahan dan pelayanan umum di bidang kebersihan dan pertamanan;

3) Membina dan melaksanakan urusan di bidang kebersihan dan pertamanan;

4) Melakukan pembinaan dan pelaksanaan tugas di bidangkebersihan dan pertamanan.

5) Perumusan kebijakan teknis di bidang kebersihan dan pertamanan;

6) Penyelenggaraan urusan pemerintahan dan pelayanan umum;

7) Penyusunan rencana kerja, pemantauan dan evaluasi;

8) Pembinaan dan pelaporan;

9) Penyelenggaraan urusan penatausahaan dinas;

10) Pelaksanaan tugas-tugas lain.

Berdasarkan Surat Keputusan Walikota Pekanbaru Nomor 07 Tahun 2004 tentang Petunjuk Pelaksanaan Pengelolaan Kebersihan bahwa Dinas Kebersihan Kota Pekanbaru dalam tugas di Bidang Kebersihan Kota Pekanbaru memiliki tanggung jawab pelaksanaan kebersihan sebanyak 24 (dua puluh empat) ruas jalan protokol antara lain: Jalan Jenderal Sudirman, Jalan Riau, Jalan Ahmad Yani, Jalan Tuanku Tambusai, Jalan Diponegoro, Jalan Cut Nyak Dien I II dan III, Jalan Gajah Mada, Jalan Pattimura, Jalan Kartini (dari Jalan Sudirman sampai jalan Diponegoro), Jalan Hang Tuah, Jalan Ir. H. Juanda, Jalan Sam Ratulangi, Jalan Prof M. Yamin, Jalan Hos Cokroaminoto, Jalan Imam Bonjol, Jalan Imam 
Munandar, Jalan Arifin Achmad (DKP Hanya Pengangkutan Pasir), Jalan Soekarno Hatta, Jalan Subrantas, Jalan SM. Amin, Jalan Khairuddin Nasution.

\section{2) Bidang Ketertiban dan Kebersihan Dinas Pasar Kota Pekanbaru}

Bidang Ketertiban dan Kebersihan merupakan unit kerja lini Dinas Pasar dalam pelaksanaan ketertiban dan kebersihan di Lingkungan Pasar. Bidang Ketertiban dan Kebersihan dipimpin oleh seorang Kepala Bidang yang berkedudukan di bawah dan bertanggungjawab kepada Kepala Dinas. Bidang Ketertiban dan Kebersihan mempunyai tugas (Rufiah 2011):

1) Mengkoordinasikan, membina dan merumuskan penyusunan ketertiban dan kebersihan serta penyusunan rencana kerja tahunan.

2) Mengkoordinasikan, membina dan merumuskan pengaturan serta penyelesaian masalah ketertiban dan kebersihan.

3) Mengkoordinasikan, membina dan merumuskan di bidang ketertiban, keamanan dan kebersihan pasar

4) Mengkoordinasikan, membina dan merumuskan penyusunan laporan, hasilhasil yang dicapai dalam pelaksanaan tugasnya

5) Mengkoordinasikan, membina dan merumuskan serta memberikan tugas teknis pelaksanaan tugas kepada bawahan

6) Mengkoordinasikan, membina dan merumuskan pelaksanaan tugas lain atas petunjuk pimpinan.

7) Melaksanakan tugas-tugas lain yang diberikan oleh pimpinan sesuai dengan tugas dan fungsinya.

\section{3) Bidang Sumber Daya Air Dinas Pekerjaan Umum Kota Pekanbaru}

Bidang Sumber Daya Air merupakan unit kerja lini Dinas Pekerjaan Umum dalam pelaksanaan pemeliharaan sumber daya air. Bidang Sumber Daya Air dipimpin oleh seorang Kepala Bidang yang berkedudukan di bawah dan bertanggungjawab kepada Kepala Dinas. Bidang Sumber Daya Air mempunyai tugas:

1) Mengkoordinasikan, membina dan merumuskan penyiapan bahan-bahan yang diperlukan Kepala Dinas dalam rangka penyusunan rencana kebijaksanaan, program kerja, petunjuk teknis dan laporan yang terkait dengan bidang sumber daya air.

2) Mengkoordinasikan, membina dan merumuskan kegiatan dalam rangka pengamanan, pemanfaatan sungai, rawa, danau, air tanah, waduk dan sumber daya alam bidang lingkungan fisik sesuai dengan program yang telah ditetapkan.

3) Mengkoordinasikan, membina dan merumuskan penyiapan bahan dan personil yang diperlukan untuk pelaksanaan pekerjaan dalam bentuk operasional pemeliharaan, perbaikan, pengamanan serta pemanfaatan prasarana dan sarana bidang sumber daya air.

4) Mengkoordinasi, membina dan merumuskan penyiapan bahan dan peralatan yang diperlukan untuk melaksanakan pekerjaan bidang sumber daya air.

5) Mengkoordinasikan, membina dan merumuskan pengendalian dan pengawasan terhadap pelaksanaan pekerjaan yang berkaitan dengan pemeliharaan, perbaikan, pembangunan baru, pengamanan dan pemanfaatan sarana dan prasarana bidang sumber daya air dan lingkungan 
fisik lainnya.Mengkoordinasikan, membina dan merumuskan pembuatan laporan atas pelaksanaan pekerjaan sesuai dengan jadwal yang ditetapkan.

6) Melaksanakan tugas-tugas lain yang diberikan oleh pimpinan sesuai dengan tugas dan fungsinya.

Seksi Operasi dan Pemeliharaan merupakan satuan kerja Bidang Sumber Daya Air dalam pelaksanaan kegiatan perencanaan, pelaksanaan dan pemeliharaan kebersihan pada saluran air (drainase). Seksi Operasi dan Pemeliharaan yang berkedudukan dibawah dan bertanggungjawab kepada Kepala Bidang Sumber Daya Air mempunyai tugas (Remanda 2012):

1) Merumuskan dan melaksanakan bahan-bahan yang diperlukan oleh Kepala Bidang Sumber Daya Air dalam rangka menyusun rencana kegiatan operasional pemeliharaan.

2) Merumuskan dan melaksanakan kegiatan dalam rangka operasi dan pemeliharaan sarana dan prasarana dibidang rawa, danau, dan pengembangan sumber daya air lainnya.

3) Merumuskan dan melaksanakan kegiatan yang berkenaan dengan operasi dan pemeliharaan sungai, rawa, danau, air tanah, waduk sumber daya alam serta lingkungan fisik tertentu sesuai dengan pelaksanaan teknis pengembangan Sumber Daya Air yang telah ditetapkan.

4) Merumuskan dan melaksanakan penyusunan rencana tahunan kerja dengan cara merinci dan menjadwalkan kegiatan yang akan dilaksanakan pada hari mendatang.

5) Merumuskan dan melaksanakan penyiapan bahan-bahan evaluasi dan laporan terhadap rencana pembangunan dan pengembangan di bidang operasi dan pemeliharaan sungai, rawa, danau, air tanah, waduk, sumber daya alam serta lingkungan fisik tertentu, perkiraan waktu banjir, pengendalian banjir, pencegahan terhadap bahaya banjir, erosi dan tanah longsor.

6) Merumuskan dan melaksanakan inventarisasi permasalahan-permasalahan yang berhubungan dengan operasi dan pemeliharaan serta menyiapkan bahan petunjuk pemecahan masalah.

7) Melaksanakan tugas-tugas lain yang diberikan oleh pimpinan sesuai dengan tugas dan fungsinya.

\section{4) Bidang Keselamatan, Teknik Sarana dan Prasarana Dinas Perhubungan, Komunikasi dan Informatika Kota Pekanbaru}

Bidang Keselamatan, Teknis Sarana dan Prasarana merupakan unit kerja lini Dinas Perhubungan, Komunikasi dan Informatika dalam pelaksanaan keselamatan, Teknik Sarana dan Prasarana yang dipimpin oleh seorang Kepala Bidang yang berkedudukan di bawah dan bertanggungjawab kepada Kepala Dinas dengan tugas sebagai berikut:

1) Mengkoordinasi, membina dan merumuskan rencana dan program kerja tahunan bidang keselamatan, teknik sarana dan prasarana transportasi

2) Mengkoordinasi, membina dan merumuskan pedomandan petunjuk tatalaksana administrasi bidang keselamatan, teknis sarana dan prasarana transportasi. 
3) Mengkoordinasi, membina dan merumuskan setiap kegiatan di bidang keselamatan, teknik sarana dan prasarana transportasi.Mengkoordinasikan, membina dan merumuskan pelayanan dan pengaturan kinerja bidang keselamatan, teknik sarana dan prasarana transportasi.

4) Mengkoordinasikan, membina dan merumuskan laporan-laporan bidang keselamatan, teknik sarana dan prasarana transportasi.

5) Mengkoordinasikan, membina dan merumuskan tugas-tugas keselamatan dan teknik sarana lalu lintas jalan, prasarana dan fasilitas lalu lintas, teknik sarana, prasarana dan keselamatan lalu lintas perairan dan udara.

6) Melaksanakan tugas-tugas lain yang diberikan oleh pimpinan sesuai dengan tugas dan fungsinya.

Seksi Prasarana dan Fasilitas Lalin Jalan merupakan satuan kerja Bidang Keselamatan, Teknik Sarana dan Prasarana dalam pelaksanaan kegiatan perencanaan, pelaksanaan dan pemeliharaan kebersihan pada lingkungan terminal dan pelabuhan. Seksi Prasarana dan Fasilitas Lalin Jalan yang berkedudukan dibawah dan bertanggungjawab kepada Kepala Keselamatan, Teknik Sarana dan Prasarana mempunyai tugas:

1) Memberi izin penyelenggaraan dan pembangunan fasilitas parkir untuk umum.

2) Menetapkan lokasi penyesuaian dan pengesahan rancang bangun terminal penumpang tipe $\mathrm{C}$.

3) Membangun pengoperasian terminal tipe $A$, tipe $B$ dan tipe $C$.

4) Menentukan lokasi, penyusunan dan pengesahan rancang bangun pembangunan terminal angkutan barang.

5) Mengoperasionalkan terminal angkutan barang.

6) Menentukan lokasi dan pengoperasian fasilitas parkir untuk umum di jalan dalam kota.

7) Melakukan kajian potensi lokasi parkir.

8) Merencanakan, membangun, mengoperasionalkan dan memelihara fasilitas terminal, bandara dan pelabuhan penumpang dan barang.

9) Merencanakan, membangun, mengoperasionalkan dan memelihara fasilitas terminal, bandara dan pelabuhan penumpang dan barang.

10)Melaksanakan tugas-tugas lain yang diberikan oleh pimpinan sesuai dengan tugas dan fungsinya.

\section{5) Badan/Dinas Lingkungan Hidup Kota Pekanbaru}

Badan/Dinas Lingkungan Hidup merupakan unsur pendukung tugas Pemerintah Daerah di Bidang Lingkungan Hidup yang mempunyai tugas sebagai berikut (B. Aprialdi, 2014):

1) Mengkoordinasikan penyelenggaraan otonomi daerah, desentralisasi, dekonsentrasi dan tugas pembantuan di Bidang Lingkungan hidup.

2) Merumuskan kebijaksanaan Pemerintah Kota Pekanbaru di bidang Tata Lingkungan dan AMDAL, pengendalian dan pemulihan lingkungan serta penataan lingkungan.

3) Mengkoordinasikan, memadukan, menyelaraskan dan menyerasikan kebijaksanaan serta kegiatan di bidang Tata Lingkungan dan AMDL, 
pengendalian pencemaran lingkungan dan pengolahan limbah, pengendalian kerusakan dan pemulihan lingkungan, dan bidang penataan lingkungan dan komunikasi lingkungan.

4) Menyusun dan melaksanakan rencana kerja dan program di bidang tata lingkungan dan $A M D A L$, pengendalian pencemaran lingkungan dan pengelolaan limbah, pengendalian kerusakan dan pemulihan lingkungan, dan bidang penataan lingkungan dan komunikasi lingkungan.

5) Memberikan pelayanan umum dan pelayanan teknis di bidang tata lingkungan dan AMDAL, pengendalian pencemaran lingkungan dan pengelolaan limbah, pengendalian kerusakan dan pemulihan lingkungan, dan bidang penataan lingkungan dan komunikasi lingkungan.

6) Melaksanakan pelatihan dibidang tata lingkungan dan AMDAL, pengendalian pencemaran lingkungan dan pengelolaan limbah, pengendalian kerusakan dan pemulihan lingkungan, dan bidang penataan lingkungan dan komunikasi lingkungan.

7) Melaksanakan tugas-tugas lain yang diberikan oleh Walikota Pekanbaru.

\section{6) Dinas Pendidikan Kota Pekanbaru}

Sesuai dengan Peraturan Walikota Pekanbaru Nomor 7 Tahun 2004 tentang Petunjuk Pelaksanaan Kebersihan Kota Pekanbaru bahwa Dinas Pendidikan merupakan Satuan Kerja Perangkat Daerah yang diberikan tugas untuk melaksanakan kebersihan di lingkungan sekolah-sekolah. Sebagai Satuan Kerja Perangkat Daerah Dinas Pendidikan Kota Pekanbaru mempunyai tugas sebagai berikut :

1) Merumuskan kebijakan teknis dalam bidang pendidikan.

2) Menyelenggarakan urusan pemerintahan dan pelayanan umum di bidang pendidikan

3) Membina dan melaksanakan urusan bidang pendidikan.

4) Membina Unit Pelaksana Teknis Dinas dalam lingkup tugasnya.

5) Menyelenggarakan urusan penatausahaan dinas.

6) Melaksanakan tugas lain yang diberikan oleh pimpinan sesuai dengan tugas dan fungsinya.

\section{7) Kecamatan se-Kota Pekanbaru}

Satuan Kerja Perangkat Daerah Kecamatan Kota Pekanbaru mempunyai tugas sebagai berikut:

1) Menangani sebagian urusan otonomi daerah serta menyelenggarakan tugas umum pemerintahan.

2) Menyelenggarakan tugas umum pemerintahan yang meliputi :

a) Mengoordinasikan kegiatan pemberdayaan masyarakat.

b) Mengoordinasikan upaya penyelenggaraan ketentraman dan ketertiban umum.

c) Mengoordinasikan penerapan dan penegakkan peraturan perundangundangan.

d) Mengoordinasikan pemeliharaan prasarana dan fasilitas pelayanan umum.

e) Mengoordinasikan penyelenggaraan kegiatan pemerintahan di tingkat kecamatan. 
f) Membina peyelenggaraan pemerintahan kelurahan.

g) Melaksanakan pelayanan masyarakat yang menjadi ruang lingkup tugasnya dan/atau yang belum dapat dilaksanakan pemerintahan keluarahan

3) Melaksanakan kewenangan pemerintahan yang dilimpahkan oleh Walikota untuk menangani urusan otonomi daerah yang meliputi aspek :
a. Perizinan.
b. Rekomendasi.
c. Koordinasi.
d. Pembinaan
e. Pengawasan.
f. Fasilitasi.
g. Penetapan.
h. Penyelenggaran dan
i. Kewenangan lain yang dilimpahkan.

Sesuai Peraturan Walikota Pekanbaru Nomor 7 Tahun 2004 tentang Petunjuk Pelaksanaan Kebersihan Kota Pekanbaru bahwa kecamatan diberikan kewenangan untuk mengelola kebersihan di wilayah Kecamatan masing-masing.

\section{KESIMPULAN}

Skema kebijakan rencana aksi daerah sampah Kota Pekanbaru dilakukandengan mengoptimalkan fungsi kelembagaan yang bertanggung jawab dalam pengelolaan sampah. Kerangka Kebijakan pengelolaan sampah Kota Pekanbaru dalam hal ini dapat dicapai melalui 3 (tiga) pilar yaitu pemerintah, masyarakat luas dan dunia usaha. Tiga pilar tersebut bekerja secara integral (terpadu), komprehensif (menyeluruh) dan mutualistik (saling menguntungkan) sesuai dengan asas kegotongroyongan dalam pengolahan sampah. Pengelolaan sampah dilakukan hanya setelah sampah ditimbulkan hal tersebut sangat bergantung pada tempat pembuangan akhir (TPA), sehingga dalam hal ini perlu adanya pelibatan pelaku usaha dan masyarakat sebagai bagian dari modal sosial strategis dalam meninjau ulang kembali kebijakan pengelolaan sampah yang selama ini didominasi pihak pemerintah saja.Kemudian juga diharapkan memberikan pemahaman kepada seluruh stakeholder terkait, baik Pemerintah Kota Pekanbaru, Dewan Perwakilan Rakyat Daerah Kota Pekanbaru dan masyarakat mengenai urgensi konsep dasar dan konsep hierarki Pengelolaan sampah yang wajib diacu dan diakomodasi dalam peraturan daerah mengenai pengelolaan persampahan.

Pada penguatan fungsi regulasi, Pemerintah Kota Pekanbaru dapat merumuskan asas-asas dan tujuan serta pasal-pasal yang akan diatur dalam Rancangan Peraturan Daerah tentang pengelolaan sampah dan menyediakan bahan-bahan hukum untuk menjalankan kewenangan dan ruang lingkup dalam kebijakan Pengelolaan sampah. Masyarakat luas dan dunia usaha di Indonesia diposisikan mempunyai kedaulatan yang sama pentingnya dengan pemerintah, sehingga harus ikut berperan dan bertanggungjawab dalam pengelolaan sampah. Pembenahan teknis pengelolaan sampah yakni dengan upaya mengantisipasi sistem pengelolaan sampah pada masa yang akan datang dengan upaya preventif, yaitu pengurangan sampah di sumbernya. Dengan adanya kajian awal mengenai kebijakan pengelolaan sampah di Kota Pekanbaru ini tentunya dapat memberikan gambaran ide peta analisis kebijakan 
pengelolaan sampahyang merujuk pada paradigma transformasi kebijakan dengan basis konsep kebijakan pengelolaan sampah terintegrasi.

\section{DAFTAR PUSTAKA}

Alam, A.S. 2016. "Analisis Kebijakan Publik Kebijakan Sosial Di Perkotaan Sebagai Sebuah Kajian Implementatif." Government: Jurnal IImu Pemerintahan 2(1): 8196.

Bryman, Alan. 2016. Social Research Methods. Oxford university press.

Damanhuri, Enri, and Tri Padmi. 2010. "Pengelolaan Sampah." Diktat kuliah TL 3104: 5-10.

Fuad, Nurhattati. 2014. Manajemen Pendidikan Berbasis Masyarakat Konsep dan Strategi Implementasi. Jakarta: Raja Grafindo Persada.

Hartati, Seri, Amir Syamsuadi, and Luluk Elvitaria. 2020. "Tranformasi Manajemen Universitas Menggunakan Framework Cobit 5 Di Era Industri 4.0." Ganaya: Jurnal IImu Sosial Dan Humaniora 3(1): 163-74.

Lestari, Ana Puji. 2014. "Program Inovasi Pengelolaan Sampah Di Kota Malang." Jurnal Administrasi Publik 2(3): 571-77.

Lubis, Hidayatullah, and Erman Erman. 2017. "Penyediaan Pelayanan Publik Dalam Persoalan Sampah Di Kota Pekanbaru Tahun 2014-2016."

Mayangkara, A.P. 2016. "Evaluasi Kebijakan Pengelolaan Sampah Di TPA Gunung Panggung Kabupaten Tuban." JPAP: Jurnal Penelitian Administrasi Publik 2(02).

Mulasari, Surahma Asti, Adi Heru Husodo, and Noeng Muhadjir. 2014. "Kebijakan Pemerintah Dalam Pengelolaan Sampah Domestik." Kesmas: National Public Health Journal 8(8): 404-10.

- 2016. "Analisis Situasi Permasalahan Sampah Kota Yogyakarta dan Kebijakan Penanggulangannya." KEMAS: Jurnal Kesehatan Masyarakat 11(2): 259-69.

Remanda, Fariz. 2012. "Pengaruh Komunikasi Interpersonal Terhadap Kinerja Pegawai Dinas Pekerjaan Umum Kota Pekanbaru."

Rufiah, Siti. 2011. "Strategi Pengelolaan Usaha Pedagang Kaki Lima Pasar Cik Puan Pekanbaru Ditinjau Menurut Ekonomi Islam."

Setiawan, Azhari, Andhik Beni Saputra, and Herry Wahyudi. 2020. "Peran Global Qurban Aksi Cepat Tanggap Indonesia Dalam Menyalurkan Bantuan Kemanusiaan Transnasional." JDP (JURNAL DINAMIKA PEMERINTAHAN) 3(1): 42-64.

Sugiyono. 2015. Metode Penelitian Kombinasi (Mixed Methods). Bandung: Alfabeta.

Suyanto, Edy, Endriatmo Soetarto, Sumardjo Sumardjo, and Hartrisari Sari Hardjomidjojo. 2015. "Model Kebijakan Pengelolaan Sampah Berbasis Partisipasi 'Green Community' Mendukung Kota Hijau." MIMBAR: Jurnal Sosial dan Pembangunan 31(1): 143-52.

Syamsuadi, Amir. 2018. "Membangun Demokrasi Pemerintahan Di Riau Dalam Perspektif Budaya Melayu." Jurnal Dinamika Pemerintahan 1(1): 1-10.

Syamsuadi, Amir, Diki Arisandi, Seri Hartati, and Bahjatul Murtasidin. 2019. "Menjadi Bijak Bagi Pemilih Pemula Berdasarkan Informasi Dari Media Sosial Di Kabupaten Kepulauan Meranti." Jurnal Pengabdian Masyarakat Multidisiplin 3(1): 27-35.

Syamsuadi, Amir, and M Zainuddin. 2018. "Strategi Pos Pemberdayaan Keluarga Dalam Penguatan Fungsi Kelembagaan Sosial di Kelurahan Binawidya Kota 
Jurnal Dinamika Pemerintahan

Vol 3. No.2 (Agustus 2020)

doi: https://doi.org/10.36341/jdp.v3i2.1279

Pekanbaru." Jurnal Dinamika Pemerintahan 1(2): 98-109.

Yulistia, Gusrini, Margaretha Suryaningsih, and Dewi Rostyaningsih. 2015. "Implementasi Kebijakan Pengelolaan Sampah Kota Semarang Menurut Perda Nomor 6 Tahun 2012 Tentang Pengelolaan Sampah." Journal of Public Policy and Management Review 4(3): 174-85. 